\title{
Heidegger, Hegel, Marx: Marcuse and the Theory of Historicity
}

Jeffry V. Ocay

1

The search for a historically conscious individual who is disposed to "radical action" is the main thrust of this paper. This is premised on the following claims: first, that the modern society is a pathological society whose rules, most often but not necessarily, imply control and domination; thus a "refusal" to abide by these rules is the most appropriate alternative available; and, second, that there is still hope for the Enlightenment's project of emancipation, that is, such "refusal," which means a political fight for liberation, is still winnable no matter how formidable the forces of domination may be. But this paper can only do so much. I do not offer any universal and prefab solution to the pathological society. What I do instead is argue that the emergence of a historically conscious individual who is disposed to "radical action," which eventually leads to a "collective radical action," is still possible today. I also argue that "radical action" presupposes an awareness of the concrete socio-historical situations, thus the importance of "historicity." This is done through a reconstructive reading of Marcuse's Critical Theory. In fact, my argument is just an echo on what Marcuse did more than four decades ago.

The paper starts with a brief discussion on "historicity" and the background of Marcuse's conception of historicity as a requisite for a theory of liberation. The discussion on Marcuse's engagement with Heidegger follows. This part is important in understanding Marcuse because, in my opinion, it was his reading of Being and Time that led Marcuse to believe that the fight for liberation must begin within the "individual" himself and not from the politically indoctrinated "proletariat" of Marx. From here, the discussion proceeds to Marcuse's appropriation of Hegel's dialectic. In his engagement with Heidegger, Marcuse realizes that Heidegger's Dasein is both asocial and apolitical, thus the possibility of a radical action is nil. Hegel's dialectic fills this gap. The progression of consciousness which results in a historically conscious individual exemplified by the "conscious slave" in Hegel's discussion of master-slave relation provided Marcuse the basis of his claim that the individual can be an active and dynamic political subject. The paper ends with a discussion on Marcuse's re-appropriation of Marx. Re-appropriation because (and it must be noted) Marcuse's pre-World War II writings are thematized by one recurring goal: the revitalization of Marxism. Thus Marcuse's reading of Lukacs, Heidegger, and Hegel is a Marxian reading. It hopes to purge the kind 
of Marxism corrupted by the orthodox Marxists. In the end, through his engagement with Hegel's "lordship and bondage" and Marx's notion of "labor," Marcuse arrives at a historically conscious individual who is disposed to radical political action.

There is nothing more decisive in Marcuse's pre-World War II writings than the notion of "historicity" for it is in the interpretation of this notion that he is able to develop his theory of liberation. For Marcuse, historicity is that which "defines history and thus distinguishes it from 'nature' or from the 'economy" and "signifies the meaning we intend when we say of something that is "historical'."' Historicity, therefore, should not be reduced to mere history as a science. As that which defines history, which is commonly understood as the telling of a particular story or narration of events that happened in a specific time and place (that is, as historiography), historicity is the underlying principle of an event. In other words, that which makes history "history" is historicity. The form and characteristic of historicity as the principle of history is simply the happening or motility of the Being of the historical. From here, it must be observed that historicity as the principle of history does not only refer to the Being of the historical, that is, Being as the subject of history per se, but historicity is nothing but the happening or the motility of the Being of beings as the subject of history. Marcuse writes: "With respect to the historical, therefore, the problem is the manner in which it $i$. The question is not history as a science or as the object of a science but history as a mode of Being." 2 And he adds: "History will be our problem as a process of happening and as a form of motility." ${ }^{3}$ But in what sense is the concept of historicity the principle of Marcuse's theory of liberation? The following discussion is entirely devoted to shed light on this question.

It is necessary at this juncture to present the background of Marcuse's conception of historicity as a requisite for the theory of liberation. Marcuse returned to Berlin after completing his doctorate from the University of Freiburg in 1922. During this time, Germany was still suffering from the socio-economic and political crisis engendered by the First World War. Upset by the present crisis, Marcuse began his systematic study of Marx and was eventually attracted to the latter's vehement critique of capitalism and the idea of socialist revolution as the best means to address such crisis. However, the rise of Soviet Marxism, especially Stalinism, perturbed Marcuse's hopeful reception of Marxism. He became dissatisfied with the Soviet Marxists' view of the "proletariat" as the only agent of the socialist revolution. In addition, Marcuse believed that Marxism had come to an impasse because of its failure to provide theoretical guidance to the German socialists during and after their defeat in the November Revolution or the German Revolution of 1918-19. As

\footnotetext{
${ }^{1}$ Herbert Marcuse, Hegel's Ontology and the Theory of Historicity, trans. by Seyla Benhabib (Cambridge, Massachusetts, London, England: The MIT Press, 1987), 1.

${ }^{2}$ Ibid.

${ }^{3}$ Ibid.
} 


\section{HEIDEGGER, HEGEL, MARX}

a result, Marcuse attempted to revitalize Marxism by looking for a corrective to this flaw somewhere else. ${ }^{4}$

The first step Marcuse undertook was the reading of Georg Lukacs's History and Class Consciousness published in 1923. Here, Marcuse was impressed by Lukacs's analysis of the reification of life under capitalism, that is, the reduction of man from active subject to inert object. But Marcuse soon lost interest when Lukacs argued that it is only the "correct practical class consciousness of the proletariat" that can address the problem of reification. ${ }^{5}$ Marcuse observes that Lukacs's "correct class consciousness" is dangerous since this gives room for the vanguardist position of Vladimir I. Lenin, who argued that the workers must have a social democratic consciousness among themselves and this must be brought to them from the outside, from the educated members of the Socialist Party. ${ }^{6}$ But most importantly, Marcuse saw that Lukacs's notion of "correct class consciousness" as the only means to address reification is flawed since those who "have not achieved this level of political and theoretical knowledge, who do not understand the social system from the class standpoint" are not inclined to radical action. ${ }^{7}$ Alluding to what Marx had argued in the Critique of the Gotha Program that the "dictatorship of the proletariat," as a political condition, can only be resorted to only if there are no other ways to reach socialism as the first stage of communism, ${ }^{8}$ Marcuse argued that it is not the proletariat but the "concrete individual" regardless of class affiliation who can be the source of a genuine total social change. Patently, Marcuse by this time had already viewed the "concrete individual" as the active agent of social change.

Marcuse read Heidegger's Being and Time in 1927, the year of its publication. According to Peter Lind, Marcuse was attracted by the questioning quality of Heidegger's thought, his engagement, his ability to go beyond established norms and customs. ${ }^{9}$ Marcuse saw an iota of hope in Heidegger's notion of "concrete philosophy" which aims at the salvation of the "concrete individual." However, Marcuse's engagement with Heidegger does not suggest a break with Marx. Rather, Marcuse's reading of Heidegger's Being and Time, ironically, led to a re-appropriation and a more heightened understanding of Marx. Lind observes that "during the period 1929 to 1933, Marcuse was vividly interested and concerned with the idea of promoting a better understanding of Marx, radically different from that of mainstream

\footnotetext{
${ }^{4}$ But towards the end of this section, it is argued that after all, Marcuse finds these "correctives" within Marx's philosophy itself.

5 Georg Lukacs, History and Class Consciousness: Studies in Marxist Dialectics, trans. by Rodney Livingstone (Cambridge, Massachusetts: The MIT Press, 1968), 205.

6 Vladimir I. Lenin, Marx, Engels, Marxism (Peking: Foreign Languages Press, 1970), 138-139.

7 See Morton Schoolman, The Imaginary Witness: The Critical Theory of Herbert Marcuse (New York: The Free Press, 1980), 9.

${ }^{8}$ Karl Marx, Critique of the Gotha Program, in Marx and Engels: Basic Writings on Politics and Philosophy, Ed. by Lewis S. Feuer (New York: Collins, 1959), 169.

${ }^{9}$ Peter Lind, Marcuse and Freedom (London and Sydney: Croom Helm, 1985), 47.
} 
Marxism...."10 This is exactly the reason why Marcuse turned to Heidegger rather than Lukacs in his attempt to correct orthodox Marxism, for what concerns Marcuse henceforth "which became the cornerstone of his thoughts throughout his life... was the emphasis on the concrete, universal individual as the subject of social and historical transformation."11 Thus, in 1929, two years after he read Heidegger's Being and Time, Marcuse decided to return to the University of Freiburg to study under Heidegger himself.

What interests Marcuse in Heidegger is the notion of "inauthenticity" which lies at the heart of Being and Time. Marcuse sees the notion of "inauthenticity" as the primordial problem that Heidegger passionately attempts to address. To understand clearly the notion of "inauthenticity" and its connection to the theory of historicity, we must look briefly at Heidegger's Being and Time.

In Being and Time, Heidegger had undertaken to analyze the dynamics and structure of Being through the use of phenomenological ontology. On the one hand, ontology for Heidegger means the theoretical inquiry which is explicitly devoted to the meaning of entities. ${ }^{12}$ On the other, phenomenology means "to let that which shows itself be seen from itself in the very way in which it shows itself from itself." 13 Thus the Heideggerian notion of phenomenology should not be understood in the literal sense, that is, phainomenon and logos, which literally means "study of things shown." 14 It must be viewed as the unconcealment of Being and Dasein's appropriation of that which is unconcealed. It is important to note that Heidegger puts more emphasis on phenomenology than the concept ontology for it is only through phenomenology that one "can have access to what is to be the theme of ontology...."15 Heidegger says that "only as phenomenology, is ontology possible."16 And what Heidegger has in mind as that which shows itself in the phenomenological conception of "phenomenon" is the Being of entities, their meaning, their modifications and derivatives. ${ }^{17}$ Then Heidegger assigns human beings as the "subject" to be analyzed. Heidegger writes: "We are ourselves the entities to be analyzed. The Being of any such entity is in each case mine."18 Inasmuch as ontology is possible only as phenomenology and that it is human beings who are the "subject" of this inquiry, it has now become clear that ontology is possible only as phenomenology of human existence. Hence, it could be inferred that Heidegger's phenomenological ontology is precisely

\footnotetext{
${ }^{10}$ Lind, Marcuse and Freedom, 19.

11 John Abromeit, "Herbert Marcuse's Critical Encounter with Martin Heidegger 1927-1933," in Herbert Marcuse: A Critical Reader, John Abromeit and W. Mark Cobb, Eds. (New York and London: Routledge, 2004), 132.

12 Martin Heidegger, Being and Time, Trans. by John Macquarie and Edward Robinson (Oxford: Basil Blackwell, 1978), 32

${ }^{13}$ Ibid., 58.

${ }^{14}$ David Macey, Dictionary of Critical Theory (London: Penguin Books, 2001), 297.

${ }^{15}$ Heidegger, Being and Time, 60.

${ }^{16}$ Heidegger, Being and Time, 60.

${ }^{17}$ Ibid.

${ }^{18}$ Ibid., 67.
} 


\section{HEIDEGGER, HEGEL, MARX}

"existential phenomenology," that is, the analysis of the Being of human beings, and Heidegger calls human beings Dasein, meaning being-there. According to Heidegger, "...Dasein is an entity which in each case I myself am." 19

If Dasein is being-there, then the question is where and how does it come to be there? The result of Heidegger's existential phenomenology as an inquiry into the Being of beings is that Dasein is being-there-in-the-world and that it has come to be in the world through "deliverance," that is, "thrownness," to use Heidegger's jargon. Heidegger declares that Dasein is "thrown" into the world and that being-in-the-world is a "thrownness." $\mathrm{He}$ writes:

This characteristic of Dasein's Being - this 'that it is' - is veiled in its 'whence' and 'whither', yet disclosed in itself all the more unveiledly; we call it the 'thrownness' of this entity into its 'there'; indeed, it is thrown in such a way that, as Being-in-the-world, it is the 'there'. The expression 'thrownness' is meant to suggest the facticity of its being delivered over. ${ }^{20}$

For Heidegger, this "thrownness" into the world necessarily implies that Dasein always exists with other entities in the world and hence, as a beingwith-others-in-the-world, Dasein is entirely submerged in the immediate care and concern of the everyday world into which it is thrown. Evidently, beingwith-others-in-the-world suggests that the existence of Dasein in the world is an existence with the "they" (das Man) or the anonymous anyone. Thus, when Heidegger says that Dasein is submerged in the immediate care and concern of the everyday world into which it is thrown, this means that Dasein is constantly related to other human beings in the form of concern and care. The term "concern" for Heidegger is Dasein's circumspective dealing with the ready-tohand-within-the-world, that is, with objects in the world. ${ }^{21}$ On the other hand, "care" is understood as Dasein's act of expressing anything about itself to itself.22 Thus, "care" is not to be understood as an ethical category, that is, an "ought" on the part of Dasein to care for others. It is rather an ontological category which is necessary for Dasein to become aware of its very own existence. It must be observed at this point that for Heidegger "concern" must be understood in terms of the phenomenon of care because according to him, in one's circumspective dealing with others, there is always a constant "care" as to the way one differs from them. ${ }^{23}$ What Heidegger would like to evince at

${ }^{19}$ Ibid., 78.

${ }^{20}$ Heidegger, Being and Time, 74.

${ }^{21}$ Ibid., 157.

22 Ibid., 227.

${ }^{23}$ Ibid., 163. It is in "care" that the notion of "intersubjectivity" comes in. Because in Dasein's act of caring for the others, that is, human beings and other entities, Dasein eventually becomes aware of its very own existence. 
this juncture is that through care, which implies the care of things and human beings, Dasein is fundamentally concerned about its mode of being, and hence becomes attuned to projecting its own possibility. Through the modes of being, namely, being-with-other, having concern for others, and taking care of the world, Dasein becomes attuned to the world. In this way, Dasein can now understand and transcend itself.

Now, implicit in the idea of "care" are the dimensions of authentic and inauthentic existence. According to Heidegger, Dasein's everyday being-withone-another in the world stands in subjection, and thus its Being is taken away by the others. ${ }^{24}$ Having "delivered over," Dasein has fallen into the "they," Dasein's existence becomes inauthentic. Heidegger writes:

"Fallenness" into the 'world' means an absorption in Being-with-one-another, in so far as the latter is guided by idle talk, curiosity, and ambiguity. Through the Interpretation of falling . . . we have (now what we) called the inauthenticity of Dasein ....25

Heidegger declares that Dasein is not aware of this inconspicuous domination by the others. Dasein is not aware that its Being is controlled by the "they," the anonymous anyone (das Man). Thus, if Dasein is to be authentic it has to have full awareness of the significance of what it means "to be," of what it means to be a self with others and objects in the world. ${ }^{26}$ Still, this requires the categories of guilt, conscience, and resoluteness. Heidegger defines guilt as a "lack" within Dasein itself, something which ought to be there but is missing. ${ }^{27}$ In relation to Dasein's Being, this lack is viewed as the "lack of authentic existence." In any case, Heidegger uses the term guilt to refer to Dasein's "lostness in the they." In relative manner, conscience is the "call of care"; it "summons Dasein's self from its lostness in the "they'." 28 As a "call of care," conscience, therefore, is the inner voice of the intellect that calls Dasein to own his existence again. If heeded, conscience will lead to resoluteness, that is, Dasein's firm determination to own his existence again, to make its existence authentic.

If inauthenticity is understood as the fallenness of Dasein into the "they," and that authenticity means full awareness of what it means to be a self with others and objects in the world, then this implies a "becoming," that is, the realization of Dasein's possibilities. Authenticity, therefore, as the full

${ }^{24}$ Heidegger, Being and Time, 164.

${ }^{25}$ Ibid., 220. Emphasis added. Note that it is in the interconnectedness of idle talk, curiosity, and ambiguity that fallenness is revealed. However, they are not necessary in this discussion. What we are concerned here is the logic behind Heidegger's existential phenomenology and its transition to Marcuse's notion of historicity. Nonetheless, skipping the discussion on these terms would not alter the logic of the whole inquiry.

${ }^{26}$ Barry Katz, Herbert Marcuse and the Art of Liberation: An Intellectual Biography (London: Verso, 1982), 68.

${ }^{27}$ Heidegger, Being and Time, 328.

${ }^{28}$ Ibid., 319. 


\section{HEIDEGGER, HEGEL, MARX}

awareness of the significance of what it means to be a self also means an "awareness of one's own-most possibilities and the firm resolve to realize them in the future." 29 This shows that authenticity is always tied to one's possibilities and to possible future ways of being, which makes manifest the "temporal" axis of the existential phenomenology_Dasein is in the present, indebted to the past, and oriented toward the future. ${ }^{30}$ In the final analysis, Heidegger's existential phenomenology revealed that "to be" is "to be in time," and "to be in time" is precisely "to be historical." As Barry Katz puts it, "Historicity is the pivotal concept in Heidegger's ontology, which refers to the way in which individuals proceed to self-awareness of the way they live in history." $31 \mathrm{He}$ adds: "It comprehends the way in which individuals relate to their own past and appropriate the tradition of which they are a part." 32 This notion of historicity then becomes the central concept in Marcuse's social theory. Let us now turn to the discussion on Marcuse's engagement with Heidegger and his re-appropriation of Marx via Hegel.

Marcuse's engagement with Heidegger centers on the analysis of Dasein and the notion of historicity. He recognizes in Heidegger the significance of the restoration of the individual's concrete existence to the center of philosophy. For sure, it was Heidegger's existential phenomenology that provided Marcuse the revolutionary subject necessary for a radical transformation of the society, a decisive subject which Marxism failed to consider. In an interview with Frederick Olafson in 1977, Marcuse says: "We saw in Heidegger what we had first seen in Husserl, a new beginning, the first radical attempt to put philosophy on really concrete foundations-philosophy concerned with the human existence, the human condition, and not merely with abstract ideas and principles." 33 But what interests Marcuse in Dasein, as the concrete existence of human beings, is the possibility of a "radical action" because that which is "concrete" is understood by Marcuse as the activity of the existential subject. ${ }^{34}$ And for Marcuse, "radical action" is deeply rooted in Dasein's existence and is the hidden disposition of the individual to change and reshape the world he is thrown into. This is a clear manifestation that Marcuse socializes Heidegger's notion of care and concern precisely because "radical action" for Marcuse is simply man's concern for the others and care of the world. In his readings on Marcuse's "Contribution to a Phenomenology of Historical Materialism," Morton Schoolman observes that Marcuse makes public that which lies private in Heidegger's notion of care and concern, that in this notion there lies an as yet unarticulated desire to create a space for the

\footnotetext{
${ }^{29}$ Abromeit, Marcuse's Critical Encounter, 135.

${ }^{30}$ Katz, Herbert Marcuse, 69.

${ }^{31}$ Ibid., 70.

32 Ibid.

33 Frederick Olafson, “Heidegger's Politics (1977): An Interview with Herbert Marcuse, in The Essential Marcuse, Selected Writings of Philosopher and Social Critic Herbert Marcuse, Andrew Feenberg and William Leiss, Eds. (Boston: Beacon Press, 2007), 116.

34 Andrew Feenberg, Heidegger and Marcuse: The Catastrophe and Redemption of History (New York and London: Routledge, 2005), 92.
} 
unnamed but no less real human potentialities, and that within the deeper dimension of human existence there lies the secret ambition to change the world. ${ }^{35}$ From here, one can notice that Marcuse no longer considers Marx's proletariat as the factor of "radical action" but it is now the ordinary individual. The struggle against oppression now rests on the concrete individual and must begin from him.

But how is "radical action" possible? Or if "radical action" is deeply rooted in the individual himself and is lying there as an unarticulated disposition, how can the individual unleash and realize this possibility? First, "radical action" is a necessary reaction to the reality of oppression in the society. And second, that this oppression leads to inauthentic existence, "radical action," therefore, is an "ought" on the part of Dasein, an inner urge to resist this kind of oppression. However, the realization of "radical action" presupposes a kind of knowledge that would make the individual act. And this knowledge is always historical because it is derived from the concrete situations. Thus, for Marcuse, an awareness of historicity is the precondition of "radical action" because an adequate grasp of the concrete situations necessitates a thorough comprehension of historicity. ${ }^{36}$

Now in Being and Time, Heidegger understood the Being and essence of Dasein historically, and that Dasein is a historical being because it is temporal. And since temporality is regarded by Heidegger as the meaning of Dasein's totality, then, again, it is the awareness of historicity that makes authentic existence possible. ${ }^{37}$ According to Alfred Schmidt, the hidden ground of historicity in Being and Time is authentic being toward death, that is, the temporality of Dasein which extends between birth and death. ${ }^{38}$ But what is crucial at this point is Heidegger's proclamation that the historical Dasein is a powerless subject of history. For Heidegger, according to Werner Marx, Dasein must surely be thought historically but in such a way that any given change would not depend upon the power of man, even though a certain role in the occurrence seems to be due to man himself. ${ }^{39}$ And, for Heidegger, part of being authentic is the acceptance of "dejection" as Dasein's fateful destiny, which implies that Dasein must accept his being delivered into his own existence and into the world, and that Dasein must accept the heritage of the past, assume it and work from there toward his very own destiny. ${ }^{40}$ But for Marcuse, authentic existence is not merely the acceptance of dejection; rather, it is a return to the past and opposes to the factual present the better of the

\footnotetext{
35 Schoolman, Imaginary Witness, 12.

${ }^{36}$ See Lind, Marcuse and Freedom, 51.

${ }^{37}$ Heidegger, Being and Timee, 425.

38 Alfred Schmidt, "Existential Ontology and Historical Materialism in the work of Herbert Marcuse," in Marcuse: Critical Theory and the Promise of Utopia, Robert Pippin, Andrew Feenberg, Charles P. Webel, and Contributors, Eds. (Massachusetts: Bergin and Garvey

39 Werner Marx, Heidegger and Tradition, trans. by Theodore Kisiel and Murray Greene (Evanston: Northwestern University Press, 1971), 163.

${ }^{40}$ Lind, Marcuse and Freedom, 61.
} Publishers, 1988), 50. 


\section{HEIDEGGER, HEGEL, MARX}

past. ${ }^{41}$ This is the essence of Dasein as a concerned being. In addition, Marcuse also rejects Heidegger's claim that authentic existence can be attained through the "practical" concern for one's own existence as the key to wellunderstood freedom. In this sense, it can be argued that Heidegger's solution to the problem of inauthenticity is based on the solitary existence that would lead to self-awareness. But for Marcuse, the solution to inauthenticity (reification in Lukacs's terminology) is a "radical action," which will eventually lead to collective radical action. Thus, according to Marcuse, in discovering the authentic historical existence made possible by the notion of concern (for others) and full knowledge of concrete historical situations, the individual becomes disposed to radical action that will finally lead to a collective radical action to change and reshape the sick society. ${ }^{42}$ It is in this claim that Marcuse departs from Heidegger.

Having turned Heidegger's Dasein inside out, having politicized Dasein, Marcuse's next concern is to explain the practicability of a "collective radical action." If Heidegger's Dasein is a passive being, and if concrete existence for Marcuse means having a disposition for radical action, then it must be explained once and for all how and under what condition the individual becomes capable of such a radical act. This issue is precisely the motif of Marcuse's Hegel's Ontology and the Theory of Historicity. As Morton Schoolman maintains, the main purpose of Hegel's Ontology is to establish the fact that the author of existence is an active and dynamic subject, a reflective subject, that reflection is a continual movement from one stage to the other, and each stage, though originally authored by the subject, places limitations upon the subsequent stage to which the subject can aspire. ${ }^{43}$

Hegel's Ontology is divided into two major parts; the first deals with Hegel's Logic and the second with Hegel's Phenomenology. Marcuse's interpretation of Hegel's Logic is not aimed at a complete understanding of the work; rather, it is focused on the theme that concerns the unfolding of the concept of Being and the process of happening implied in it. Here, the concept "dialectic" takes center stage. The point Marcuse wants to convey in his interpretation of Hegel's Logic is that all things are incessantly in the act of becoming, and negativity is the underlying principle. In Hegel's dialectic, the thesis Being is transformed into its antithesis non-Being through the process of negation; inevitably, the antithesis non-Being (Nothing) which is deduced from the thesis Being is then again negated which leads to the third category, namely, Becoming. ${ }^{44}$ As Marcuse writes: "All being is a having become . . . and a becoming ... of another being. All being is related to an unending multiplicity of other beings through its origins, and springing forth out of its origins ..., it

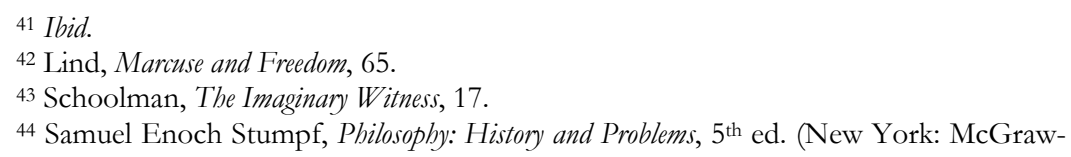


re-enters a new manifold." 45 According to Hegel, this is the "very nature and essence of everything... the law of things and of the finite as a whole." 46

For Marcuse, as for Hegel, this movement is not directionless because it is guided by the idea of "motility," defined as the Being that comprehends, which aims at the purest actualization of Being. ${ }^{47}$ The dialectic, therefore, is a kind of movement that purifies Being through a series of negations until it reaches what Hegel calls the Absolute Idea. Thus, the Being in the very beginning which undergoes multiple changes is the same Being that reaches purity; it is the Being that has been in the past, is in the present, and will be in the future. According to Marcuse, this movement is characterized by the idea of unity in multiplicity, that is, identity in difference.

In Hegel's dialectic, Marcuse explains that in the beginning is the idea of original unity or the absolute totality. This absolute totality is the true unity which must be understood as the meaning of Being. Thus for Hegel, the notions "original unity," "absolute totality," and "Being" are one and the same. The absolute totality, which is the origin of being, allows being to spring forth out of itself, and as the original unity, it first gives unity over and against all opposites. ${ }^{48}$ Thus, the absolute as totality is not to be understood as the sum total of all things; it is simply that which constitutes the proper being of all that exists. The absolute is the Being which lies at the ground of all beings, which is present in them and which gives unity among them. ${ }^{49}$ In other words, the absolute is the underlying principle of all that exists. Now, it should be remembered that Hegel's goal which is the Absolute Idea is no different from the absolute totality which exists from the very beginning of the dialectic. For Hegel, the process of the purification of Being which lies at the heart of the dialectic is actually a returning back to the original unity; it is precisely a process of going back to itself, to its original and purest form. This means that the Absolute Idea or "original unity" was there from the very start but has regressed. Thus, the dialectic, which is the history of the progression of consciousness, is a process of attaining the ideal state (the Absolute) through recollection or remembrance of the things past, through remembrance of the "original unity." To understand this clearly, this needs an investigation of the unfolding of Being in the dialectical process itself.

The absolute as totality contains within itself the manifold of bifurcation. Bifurcation is the juxtaposition of beings within the totality of the absolute-the opposites of spirit and matter, soul and body, faith and understanding, freedom and necessity, being and not-being, concept and being,

${ }^{45}$ Marcuse, Hegel's Ontology, 11.

${ }^{46}$ Georg W. F. Hegel, Hegel's Logic, translated from the Encyclopaedia of Philosophical Sciences by William Wallace (Oxford: Clarendon Press, 1975), 116.

47 Marcuse, Hegel's Ontology, 4. Though Marcuse buys Hegel's dialectic, it must be noted that like Adorno, and the rest of the first generation of Critical Theorists, Marcuse does not accept the Hegelian teleology. For Marcuse, as for Adorno, the dialectic is permanent, that is, the Absolute is impossible.

48 Ibid., 22.

${ }^{49}$ Marcuse, Hegel's Ontology, 22. 


\section{HEIDEGGER, HEGEL, MARX}

finitude and infinity. ${ }^{50}$ In general, bifurcation is the juxtaposition of subjectivity and objectivity, a juxtaposition which is at the same time a unity in itself. Being inherent in the absolute itself, bifurcation is thus the original unity which allows the world of oppositions and limitations to spring forth from itself. In essence, bifurcation is simply the self-positing or the appearing of the absolute, and this is necessary on the part of the absolute because its primary function is to manifest itself; it is this specific motion of bringing itself forth, of showing itself, which constitutes the proper "actuality" of beings. ${ }^{51}$ Hegel equated bifurcation with self-positing or appearing because when the absolute posits itself, it posits itself in duality. That is, when something exists or appears, it makes itself the opposite of anything else. For example, once a chair exists (appears), it becomes distinct from the rest of all things; it becomes the opposite of all things that are not identical to itself. In other words, the existence of a thing is a necessary negation of all things; the chair is a negation of the table, the room, the tree, just as they are a negation of the chair. This bifurcation, this fundamental split and dual character of reality, according to Marcuse, is the ground of the motility of Being-Being becomes a motility, it becomes a happening because it bifurcates itself, it manifests itself, that is, it makes itself "actual." Nonetheless, there is identity in this difference because the chair is a chair only if it is juxtaposed with the table, tree or room. Hegel calls this identity in difference or absolute unity Absolute Idea, the conscious identity of the finite and the infinite, that is, the unification of opposites; the Absolute Idea is the actual being in its highest truth. ${ }^{52}$ But Marcuse argues that Being comes first to its truth as Idea, then Life, the Being of humans, moves to the center of ontology, and, finally, the Absolute Idea becomes actual. ${ }^{53}$ In conclusion, the dialectical process which starts from the absolute or the original unity of subjectivity and objectivity, which then manifests itself from itself and negates itself through bifurcation, and then transforms itself by way of regression, and finally reaches a completion in the Absolute Idea is nothing than the "history of beings." Indeed, the dialectic is precisely the history of beings out of which Life emerges. In the first part of Hegel's Ontology, Marcuse arrives at the following conclusions:

1) The thesis that the meaning of Being consists in the original unity of subjectivity... and objectivity....and the formulation of this unity as a process of development of beings themselves... dissolves traditional ontology into a history of beings. The different regions of beings then unfold as varied forms of a processual happenings;

2) Because beings are understood as structures of unifying unity in movement, the dimension of essence is disclosed as the actual havingonce been, as the timeless past, of beings. Their having-been is a

\footnotetext{
${ }^{50}$ Ibid., 9.

51 Ibid., 43.

52 Marcuse, Hegel's Ontology, 170.

${ }^{53}$ Ibid., 194.
} 
decisive factor in the history of beings. It is this dimension which first allows the unity of the process of becoming of beings as independent selves in otherness. The dimension of having-been gives the unity of this "ground" and its identity. The dimension of essence is where beings retreat from their immediate presence back into themselves; it is in the sphere of mediation wherein beings grasp their present existence (Dasein) as a presupposition of their essence, and through their essence transform it into "posited being." Mediation, presupposition, and posited being will later prove themselves as the essentially historical categories of Hegelian ontology; a being that exists in this fashion is a historical one;

3) The history of beings is directed from within toward an immanent goal: it reaches completion in the freedom and truth of a being that comprehends, in the Being of the Idea. Beings come first to their truth as Idea; only as Idea is their process a true one. With this claim, however, the Being of humans, Life itself, moves to the center of ontology. For Life is the first form in which concept is realized in its truth and freedom, and in which the Idea of Being has become actual. First with the being of Life do all entities grasped by Life become actual and manifest their truth. ${ }^{54}$

As mentioned, Marcuse's engagement with Hegel's Logic is concerned mainly with the unfolding of Being; it shows that the dialectical process in itself is nothing but the history of Life. Also in the Logic, Marcuse has only considered the reality of Life in a more general sense; Life is not yet analyzed in its total concreteness. Thus, the question regarding the condition which makes the individual capable of radical action is not yet fully addressed. But as expected, this issue preoccupies Marcuse in the second part of Hegel's Ontology. Marcuse's engagement with Hegel now moves from the Logic to the Phenomenology, from a general conception of Life to the concrete and specific way of human life.

Life is introduced as self-consciousness in Hegel's Phenomenology and, just as in the Logic, Life in the Phenomenology is considered as a process, but this time a process which results in a concrete knowing "I," the individual. In the process of individuation, self-consciousness begins with "desire." In fact, Hegel declares that desire is in itself self-consciousness. ${ }^{55}$ Desire, however, should not be understood in the psychological sense as a craving for something that satisfies physiological needs. Desire for Hegel simply means the original attitude of the "I" toward self-consciousness. In other words, desire is the necessary tendency of the knowing "I" to make itself actual; it is indeed the necessary self-showing of the knowing "I." The satisfaction of this desire is

54 Marcuse, Hegel's Ontology, 193-194.

55 Georg W.F. Hegel, The Phenomenology of Mind, trans. with an introduction and notes by J.B. Baillie (London: George Allen \& UNWIN LTD, 1949), 225. 


\section{HEIDEGGER, HEGEL, MARX}

precisely the fulfillment of the actual Being of the "I," but this can only be attained through a dialectical interaction with another conscious self. According to Hegel, self-consciousness exists in itself and for itself only by being recognized by the other conscious self, thus Hegel's theory of recognition. ${ }^{56}$ For Marcuse, this process is a "we-like" process of Life, and, in here, there is an essential reciprocal dependence, there is an essential demand for reciprocal recognition. ${ }^{57}$

With the "we-like" process of Life, Marcuse realizes that human life is basically a struggle for self-subsistence, for freedom. He says that the essence of self-consciousness is freedom. ${ }^{58}$ This can be fully grasped through Hegel's idea of dependence and independence exemplified by master-slave relationship.

In the master and slave relation, the master has not recognized the slave as an essentially independent being because at first, the master thinks of himself as the only independent being. But when the master achieved real lordship he realizes that he has achieved not independent consciousness but a dependent one. The master realizes that he is dependent upon his subject, upon the slave; $;^{59}$ he is totally dependent upon the toil of the slave. On the other side, the slave, who in the beginning views his plight as legitimate, also realizes that he is truly independent and it is the master that depends upon him, especially on the fruits of his labor. ${ }^{60}$ Thus, it is through labor that the slave realizes that he is truly free. But this does not mean that the slave automatically becomes "free" upon realizing via the notion of labor that it is him and not the master who is truly free. After all, he is still a slave. The slave still needs to fight for his freedom.

Marcuse sees labor therefore as the principle of freedom. This is now the most crucial point of Marcuse's engagement with Hegel and as an answer to the question posed earlier: through labor, the individual attains a level of concrete consciousness that would make him disposed to radical action. Inasmuch as this realization is viewed as the result of the movement of Life, that is, as history, the claim that Marcuse's theory of historicity as his first theory of liberation is given a sound grounding; the abstract notion of "historicity" becomes concrete with the idea of "self-consciousness," which can dispense the individual the necessary insight for radical action. Another important implication that could be drawn from Marcuse's Hegel's Ontology is that this self-consciousness, which, again and again, makes the individual disposed to radical action, results in a necessary union between theory and praxis. Self-consciousness viewed by Hegel as Absolute Spirit is now taken by Marcuse to mean a "knowledge that acts and action that knows." Finally, Marcuse's appropriation of Hegel reveals clearly his tacit break with Heidegger even before the latter publicly declares his pro-Nazi leanings. Heidegger's Dasein is predetermined by the a priori elements of experience. Dasein needs to

\footnotetext{
56 Ibid., 229.

${ }^{57}$ Marcuse, Hegel's Ontology, 251.

58 Ibid. 254.

${ }^{59}$ Hegel, Phenomenology, 237.

${ }^{60}$ Ibid.
} 
accept its dejection and work from there. Dasein must attune itself to Being and appropriate that which is unconcealed by Being itself. For Heidegger, this is the way to authenticity, to Dasein's act of attaining authenticity. But with his analysis and appropriation of Hegel, Marcuse insists that the determination of radical action is not something imposed upon the individual from without; rather, it is expressed by the individual from within. The individual is not determined by some pre-given elements of experience or "existential givens" as Heidegger would have us believe. On the contrary, Marcuse argues that it is the individual that creates not only his own existence but the subjective and objective determinants of this existence. In other words, it is the individual that shapes society and it is the same individual that moves history, and that "dejection" is a social and historical construction. In addition, Marcuse argues that Hegel's subject is freer than Heidegger's Dasein and that Hegel's subject does not engage in practical activity without first of all attaining a theoretical knowledge which is closely tied to the social and political life. ${ }^{61} \mathrm{It}$ is in Hegel's philosophy, therefore, that Marcuse's theory of historicity achieves a level of concreteness and not in Heidegger's existential ontology.

Time and again, it must be remembered that from the very outset Marcuse never intended himself to become a disciple of Heidegger. He studied Heidegger in order to revitalize Marxism. Heidegger's influence on Marcuse therefore is no more than a mere inspiration or simply a guide to what the latter had been looking for. This became evident when Marcuse cast off Heidegger after reading the newly published Economic and Pbilosopbical Manuscripts of 1844. In these manuscripts, Marcuse realized that the correctives to orthodox Marxism were actually lying at the very heart of Marx's philosophy. Via Hegel's notion of labor, the discovery of the Paris Manuscripts enabled Marcuse to finally lay down his first theory of human liberation without the help of Heidegger's existential phenomenology. The attempt to fuse Heidegger's existential philosophy and Marx's socialism had been abandoned and Marcuse's theory of historicity was now focused on Marx's notion of labor. The next discussion deals with Marcuse's reengagement with Marx.

Marcuse insists that the manuscripts called for a re-interpretation of the meaning of the theory of historical materialism. Contrary to previous claims that the theory is rooted in purely economic grounds, that "history develops according to rigid economic laws that establish socialism as its necessary and inevitable outcome," ${ }^{2}$ Marcuse argues that Marx's historical materialism is a history of the active individual making himself free through labor; economics is not the end, but rather the means to the realization of man's potentialities. "Far from being mere economic activity..., labor is the 'existential activity' of man, his 'free conscious activity' — not a means for maintaining his life...but for developing his 'universal nature'. ${ }^{63}$

${ }^{61}$ Schoolman, Imaginary Witness, 21.

${ }^{62}$ See Schoolman, The Imaginary Witness, 22.

${ }^{63}$ Herbert Marcuse, Reason and Revolution: Hegel and the Rise of Social Theory, $2^{\text {nd }}$ edition with supplementary chapter (London and Henley: Routledge and Kegan Paul, 1955), 275. 


\section{HEIDEGGER, HEGEL, MARX}

For Marcuse, as for Marx, labor is man's affirmation of his being because through labor, man can produce and reproduce an external, material objective world. ${ }^{64}$ Through labor, man is able to transform and appropriate the material objects he encounters to satisfy his needs, a satisfaction necessary for the full realization of his potentialities and his becoming a truly free being. Put differently, labor is man's act of perfecting himself. It appears therefore that labor is man's essence; it defines himself as conscious being distinct from the brutes. Thus, in producing and reproducing the objective world to his advantage,

man proves himself a conscious species being, i.e., as a being that treats the species as its own essential being, or treats himself as a species being. Admittedly, animals also produce. They build nests, dwellings, like the bees, beavers, ants, etc. But an animal only produces what it immediately needs for itself or its young. It produces one-sidedly, whilst man produces universally. It produces only under the dominion of immediate physical need, whilst man produces even when he is free from physical need and only truly produces in freedom therefrom. An animal produces only itself, whilst man produces the whole of nature. An animal's product belongs immediately to its physical body, whilst man freely confronts his product. An animal forms things in accordance with the standard and the need of the species to which it belongs, whilst man knows how to produce in accordance with the standard of every species, and knows how to apply everywhere the inherent standard to the object. Man therefore also forms things in accordance with the laws of beauty.

It is just in his work upon the objective world, therefore, that man first really proves himself to be a species being. This production is his active species life. Through and because of this production, nature appears as his work and his reality. The object of labor is, therefore, the objectification of man's species life: for he duplicates himself not only, as in consciousness, intellectually, but also actively, in reality, and therefore contemplates himself in a world that he has created. ${ }^{65}$

64 Herbert Marcuse, "The Foundation of Historical Materialism," in The Essential Marcuse, Selected Writings of Philosopher and Social Critique Herbert Marcuse, eds. by Andrew Feenberg and William Leis (Boston: Beacon Press, 2007), 83.

${ }^{65}$ Karl Marx, Economic and Philosophic Manuscript, ed. with an Introduction by Dirk J. Struik, trans. by Martin Milligan (New York: International Publishers, 1964), 113-114. 
But the realization of the goal of labor is not as easy as it seems to be. Because the individual is social by nature, his labor cannot escape the systematic organization of labor in society, which always involves the system of control and domination. This is true in a capitalist society. Under capitalism, all aspects of the labor process, for example, what are and how much to be produced, how are prices and wages to be determined, and things like these, are solely determined by the capitalist themselves. Marx rightly puts it that the sole motive of the capitalist is nothing but the consideration of his own profit. The role of capital and profit is crucial here. Marx is convinced that the employment of capital is intended solely for the acquisition of more and more profits and not for the benefit of the whole society. He sees that the "plans and speculations of the employers of capital regulate and direct all the most important operations of labor, and profit is the end proposed by all those plans and projects." 66

The obstruction of the goal of labor is explained fully in the notion "alienation of labor." Man's act of perfecting himself through labor is deterred since under capitalism, the fruit of his labor is no longer his own but possessed and manipulated by the other, the capitalist; the product of his labor becomes an independent object existing outside himself, a powerful object that confronts him. This is the alienation of man from himself as a result of being alienated from the fruits of his labor. But inasmuch as man becomes his true self only if he is related to another self, then man's alienation from himself is at the same time an alienation from his fellowmen. Marcuse observes that alienation of labor in general has set individuals in society against each other. "They are linked in the commodities they exchange rather than their persons." ${ }^{\prime \prime} 7$ What is worst is that the individuals themselves are reduced to the level of commodities. "Labor produces not only commodities: it produces itself and the workers as a commodity...." 68

Alienation of labor in general is characterized by the fact that labor under capitalism makes the worker discontent and unhappy. This is because every time the worker labors for the capitalist, and since the latter has no other interest than the accumulation of more profits, the poorer he becomes. This follows the law of inverse proportion in the accumulation of profit and the compensation of the workers: the more the capitalist maximizes profit, the more wage is minimized. Alienation of labor therefore necessarily implies pauperization. With this condition, the worker "does not develop freely his physical and mental energy but mortifies his body and ruins his mind." 69 His labor therefore is not voluntary but coerced; it is indeed forced labor. Under capitalism, the worker is not free. He only "feels himself freely active in his animal function - eating, drinking, procreating, or at the most in his dwelling and in dressing-up, etc.; and in his human functions he no longer feels himself

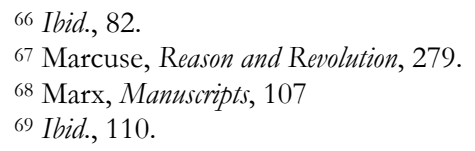




\section{HEIDEGGER, HEGEL, MARX}

to be anything but an animal. What is animal becomes human and what is human becomes animal." 70

Alienation of labor is concretely manifested in "private property." Marx believes that it is private property that completes the dominion over man. Thus, Marx's solution to the problem of alienation of labor is not the abolition of labor per se, but the total abolition of private property. However, it is a mistake to view the abolition of private property as the abolition of the fruits of man's labor. In the Communist Manifesto, Marx clearly states that there is no need to abolish the hard-won, self-acquired private property of the individual. ${ }^{71}$ The individual finds satisfaction in this property, and through this, he is able to proceed to perfecting himself. So, when Marx called for the abolition of private property, he meant the bourgeois private property. It is the institutionalized bourgeois private property or "capital," which exploits the laborer that must be abolished.

For Marx, according to Marcuse, there are two forms of private property, namely: 1) estranged private property, and 2) true form of private property. The first is merely private property, that which is the result of the capitalist mode of appropriation. Marcuse opines that this form of private property consists in an untrue mode of having and possessing and its use is based either in immediate consumption or in its capacity to be turned into capital. ${ }^{72}$ Here, life stands in the service of property instead of property in the service of life. ${ }^{73}$ True form of private property on the other hand is simply those objects whose availability and usability enable the free realization of man's essence, that which enriches and completes his entire being. This does not mean, however, that man simply and directly has to have and possess them; man needs to appropriate them through labor. True private property, therefore, implies that the product of man's labor becomes an integral part of his nature. In this way, labor is no longer an alienated activity, but all-around self-realization and self-expression. ${ }^{74}$ Marcuse argues that this is the way to the emancipation of man, or, in Marx's words, the realization of the "total man."

With Marx's notion of labor, Marcuse's theory of historicity as a theory of liberation is now arrived at. Labor as a practical activity is not merely instrumental, i.e., as means to an end, as means to self-development and selfcreation, but a reflective activity that makes the individual "historically conscious" and enables him to transform nature to his advantage. Labor produces in man "insight," that is, an understanding into the historical and social situation, a real knowledge of the structure and operations of the entire social system. For Marcuse, this "insight" makes the individual disposed to radical action, and thus enables him to oppose and abolish all forms of control and domination. Through labor, man becomes the lever of the revolution.

\footnotetext{
${ }^{70}$ Marx, Manuscripts, 111.

${ }^{71}$ Karl Marx, Communist Manifest, in Karl Marx and Frederick. Engels, Selected Works, Vol. 1 (Moscow: Foreign Languages Publishing House, 1958), 47.

72 Marcuse, Historical Materialism, 98.

${ }^{73}$ Ibid.

${ }^{74}$ Marcuse, Historical Materialism, 99.
} 
In the final analysis, Marcuse's theory of historicity shows that the individual is the key agent of the revolution and it is not the "correct class consciousness" of the proletariat as Marx, and later Lukacs, would have us believe. It is not even the apolitical and solitary Dasein of Heidegger. Through his engagement with Hegel's "lordship and bondage" and Marx's notion of "labor," Marcuse arrives at a historically conscious individual who is disposed to radical political action. As Morton Schoolman opines, Marcuse's theory of historicity as a theory of liberation constituted the recognition of the radical individual as a viable political unit, as the hope of the revolution. ${ }^{75}$

Department of Philosophy, Siliman University, Philippines Department of Philosophy, Macquarie University, Australia

\section{References}

Abromeit, John, “Herbert Marcuse's Critical Encounter with Martin Heidegger 1927-1933," in Herbert Marcuse: A Critical Reader, edited by John Abromeit and W. Mark Cobb (New York and London: Routledge, 2004).

Feenberg, Andrew, Heidegger and Marcuse: The Catastrophe and Redemption of History (New York and London: Routledge, 2005).

Hegel, Georg W. F., Hegel's Logic, trans. by William Wallace (Oxford: Clarendon Press, 1975). The Phenomenology of Mind, trans. by J.B. Baillie (London: George Allen \& UNWIN LTD, 1949).

Heidegger, Martin, Being and Time, trans. by John Macquarie and Edward Robinson (Oxford: Basil Blackwell, 1978). The Question Concerning Technology and Other Essays, trans. by William Lovitt (New York and London: Garland Publishing, 1977).

Katz, Barry, Herbert Marcuse and the Art of Liberation: An Intellectual Biography (London: Verso, 1982).

Lenin, Vladimir, Marx, Engels, Marxism (Peking: Foreign Languages Press, 1970).

Lind, Peter, Marcuse and Freedom (London and Sydney: Croom Helm, 1985).

Lukacs, Georg, History and Class Consciousness: Studies in Marxist Dialectics, trans. by Rodney Livingstone (Cambridge, Massachusetts: The MIT Press, 1968).

Macey, David, Dictionary of Critical Theory (London: Penguin Books, 2001).

Marcuse, Herbert, Hegel's Ontology and the Theory of Historicity, trans. by Seyla Benhabib (Cambridge, Massachusetts, London, England: The MIT Press, 1987).

, Reason and Revolution: Hegel and the Rise of Social Theory, $2^{\text {nd }}$ edition

with supplementary chapter (London and Henley: Routledge and Kegan Paul, 1955).

${ }^{75}$ Schoolman, Imaginary Witness, 34-35 


\section{HEIDEGGER, HEGEL, MARX}

, "The Foundation of Historical Materialism," in The Essential Marcuse, Selected Writings of Philosopher and Social Critique Herbert Marcuse, edited by Andrew Feenberg and William Leis (Boston: Beacon Press, 2007).

Marx, Karl, Critique of the Gotha Program, in Marx and Engels: Basic Writings on Politics and Philosophy, edited by Lewis S. Feuer (New York: Collins, 1959).

, Economic and Philosophic Manuscript, trans. by Martin Milligan (New York: International Publishers, 1964).

, Communist Manifest, in Karl Marx and Frederick Engels, Selected Works, Vol. 1 (Moscow: Foreign Languages Publishing House, 1958).

Marx, Werner, Heidegger and Tradition, trans. by Theodore Kisiel and Murray Greene (Evanston: Northwestern University Press, 1971).

Olafson, Frederick, "Heidegger's Politics (1977): An Interview with Herbert Marcuse, in The Essential Marcuse, Selected Writings of Philosopher and Social Critic Herbert Marcuse, edited by Andrew Feenberg and William Leiss (Boston: Beacon Press, 2007).

Schmidt, Alfred, "Existential Ontology and Historical Materialism in the work of Herbert Marcuse," in Marcuse: Critical Theory and the Promise of Utopia, edited by Robert Pippin, Andrew Feenberg, Charles P. Webel, and Contributors (Massachusetts: Bergin and Garvey Publishers, 1988).

Schoolman, Morton, The Imaginary Witness: The Critical Theory of Herbert Marcuse (New York: The Free Press, 1980).

Stumpf, Samuel Enoch, Philosophy: History and Problems, 5th ed. (New York: McGraw-Hill, 1994). 